\title{
BUSINESS
}

\section{Nuclear's core business}

\section{The job of cleaning up Britain's nuclear plants is up for auction - so who might profit from the newly privatized industry? Andrea Chipman reports.}

ast month, the UK government announced that it will split its nuclear-site management and clean-up business. British Nuclear Group (BNG) is to divide into two separate parts, re-tendering its largest contract rather than being sold off in one piece as originally planned. This was just the latest tweak to the process of creating a marketplace for the cleanup of Britain's nuclear legacy that continues to keep the nuclear business and potential investors on their toes.

Over the next six years, the Nuclear Decommissioning Authority (NDA) - a public body created in 2005 to take strategic responsibility for 20 civil nuclear sites - will open the clean-up contracts to bidding. Other sites that will ultimately go to tender include a handful of military facilities and eight nuclear reactors owned by electricity company British Energy, which haven't yet reached the end of their lifespans.

\section{Powering down}

Sites slated for clean-up include Dounreay, a 1950s research reactor at Caith-

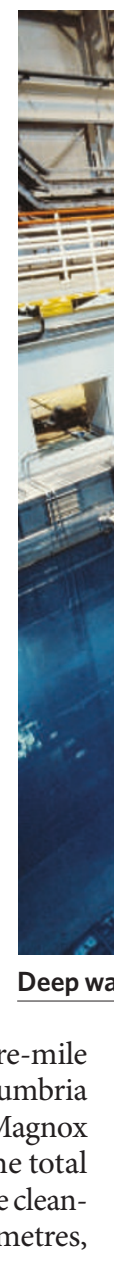

"The opportunities are increasing for private companies, but there's more competition." - Peter Higton ness in Scotland, Sellafield, a two-square-mile nuclear facility on the England's West Cumbria coast, and some of the first-generation Magnox power plants. It will be a huge task. The total volume of radioactive waste subject to the cleanup is forecast to total 2.3 million cubic metres, according to a 2004 inventory report by Nirex, the nuclear waste management agency.

The NDA, which is due to come up with a 'definitive' cleanup figure for the government by April 2008, currently spends $£ 2.2$ billion (US $\$ 4.2$ billion)

reprocessing plants, Sellafield is likely to require the most technical ingenuity of contractors. "There's so much radioactive hazard there that when you work on one part, you need to be aware of everything else around it," says Paul Vallance, a spokesman for BNG.

In addition to the government-owned United Kingdom Atomic Energy Agency (UKAEA), which is currently responsible for cleaning up Dounreay, a number of other companies are keen to enter bidding. US engineering giant a year on clean-up contracts. Meanwhile, the government's estimates of the cost of the cleanup have been rising by some $10 \%$ a year for the past four years and have recently topped $£ 63$ billion. But some industry insiders believe the figure is nearer $£ 85$ billion, others double that.

Sixty per cent of total clean-up costs are expected to be used up at Sellafield, which operator BNG refers to on its website as "the most challenging nuclear site management programme in the world". With huge water tanks containing radioactive waste and fuel
Bechtel said earlier this month that it had formed a consortium with BWX Technologies, a nuclear facilities management firm in Lynchburg, Virginia, and UK services firm Serco Group to compete for contracts. Fellow UK services company Amec, which already subcontracts on 250 nuclear clean-up projects in Britain, has joined with UKAEA and $\mathrm{CH} 2 \mathrm{M}$ Hill, an engineering company in Englewood, Colorado, to bid in the new market.

"The opportunities are increasing for private companies, but there's more competition, says Peter Higton, managing director of Amec NNC, the company's nuclear division.

Less clear, say analysts, is how investors' requirements will dovetail with the government's remit to open the nuclear clean-up market to competition.

Given that the decommissioning market is one that will shrink over time, government contracts are likely to be appealing to companies only if they offer dependable profits, says Ian Jackson, an independent nuclear-industry analyst and head of UK firm Jackson Consulting. The pending break-up and sale of BNG, which holds the lion's share of nuclear clean-up contracts, is a case in point, he adds.

In a research report earlier this month, Jackson discussed the "paradox" of the government's nuclear privatization strategy: "Its largest player, BNG, is worth little to investors if it has no forward contracts, making the firm difficult to sell. But granting forward contracts that continue BNG's existing monopoly position will destroy the market diversity that the NDA is trying hard to achieve."

\section{Investor incentives}

Ultimately, Jackson adds, the component businesses of BNG are likely to be sold at a "knockdown price" that allows investors to bet on those businesses winning clean-up work without having long-term forward contracts included in the sales agreement. Another attraction for companies is to boost profits by using new clean-up technologies, says Clive White, head of Amec's UK operations.

Amec's US nuclear business, for example, has developed its own proprietary technology, Geomelt, which uses electric currents to melt radioactive and chemical wastes into a manageable glass-like material for safe storage. UKAEA has had some limited success applying marine technology by using remotely operated vehicles to detect and clean up radioactive contamination found on the sea bed and beaches near Dounreay. Other approaches, such as applying nanomaterials to the immobilization and storage of radioactive waste, are still at the early stages of development.

In theory, the long-term financial rewards for investors could be significant. The NDA's strategy paper of March 2006 says the authority will consider raising the $4.4 \%$ fee for performance that it awards contractors to as much as $15 \%$. Under this higher calculation, Jackson notes, the Sellafield business could be worth as much as $£ 451$ million alone, with the Magnox plant clean-ups valued at more than $£ 500$ million. 